\title{
Encapsulation of Sour Cherry Pomace Extract by Freeze Drying: Characterization and Storage Stability
}

\author{
Vesna Tumbas Šaponjac,* Gordana Ćetković, Jasna čanadanović-Brunet, \\ Sonja Đilas, Biljana Pajin, Jovana Petrović, Slađana Stajčić \\ and Jelena Vulić
}

\author{
University of Novi Sad, Faculty of Technology, Bulevar cara Lazara 1, 21000 Novi Sad, Serbia \\ * Corresponding author: E-mail: vesnat@ uns.ac.rs \\ Tel: +381214853763; Fax: +38121450413
}

Received: 03-08-2016

\begin{abstract}
In this study sour cherry pomace was extracted with food-grade solvent (50\% ethanol), concentrated and stabilized in whey and soy proteins by encapsulation. Soy proteins exhibited higher encapsulation efficiency (94.90\%), but not significantly $(\mathrm{p}<0.05)$, from whey $(90.10 \%)$. Storage properties of whey (WP) and soy protein (SP) encapsulates in terms of total polyphenols, anthocyanins and antioxidant activity were tested for 6 weeks. At the end of storage period the retention of polyphenols in SP and WP was similar (67.33 and 69.30\%, respectively), while the content of anthocyanins has increased in SP (for 47.97\%) and decreased in WP (for 1.45\%). The decrease in antioxidant activity in SP (12.22\%) was lower than in WP (35.04\%). Colour parameters of encapsulates have followed the similar trend as anthocyanin change during storage. The technique reported herewith can be used for obtaining quality encapsulates for their use as functional food additives, as a way of fruit waste valorization.
\end{abstract}

Keywords: Sour cherry, encapsulation, polyphenols, antioxidant activity, colour

\section{Introduction}

Polyphenols have attracted the interest of many researchers and the general public due to the potential health benefits to humans, resulting from their antioxidant, anti-inflammatory, cardioprotective, and neuroprotective activities, inhibition of bacterial, viral, or fungal infections, development of tumors, and interaction with proteins, such as enzymes, tissue proteins, and membrane receptors. Based on these facts employment of polyphenols in food, pharmaceutical and biomedical fields is suggested. ${ }^{1}$ The fate of dietary polyphenols during thermal food processing is associated with destruction of some primary compounds and introduction of many new compounds, and can lead to alterations in foods' organoleptic properties and, more importantly, biological activities. It was suggested that during future functional food development by means of dietary polyphenol fortification before food processing, cautious measures are required to efficiently retain the primary chemical structure and the structure-associated health-beneficial bioactivities of polyphenols during thermal treatment. ${ }^{2}$ Some polyphenols show low water solubility and low stability to other environmental conditions (exposure to light, oxygen, and enzymatic activities) and may undergo degradation in water or oxidation, with a consequent loss in activity. Also, some of them have a high rate of metabolism and rapid elimination from the human body (e.g. non-conjugated polyphenols). ${ }^{3}$ Additionally, high molecular weight polyphenols (tannins, proanthocyanidins etc.) cannot be easily absorbed. ${ }^{1,3,4}$ Further, phenolics are instable in various solutions and therefore it is necessary to coat them in order to stabilize them which can be achieved by the process of encapsulation. This process prolongates the shelf life of the phenolics and accompanied biochemical functionalities, and eases the incorporation of such components into certain food products due to prevention of lumping, improving flow ability, compression and mi- 
xing properties, reducing core particle dustiness and modifying particle density. ${ }^{5,6}$

Polyphenolics from various sources have been encapsulated in predominantly protein and polysaccharide carriers and their mixtures. For example, beetroot juice was encapsulated in maltodextrin, Arabic gum and a mixture of both, ${ }^{7}$ saffron and beetroot extracts in maltodextrin, gum Arabic, modified starch and chitosan, ${ }^{8}$ pomegranate peel, ${ }^{5}$ green tea and olive pomace in maltodextrin, ${ }^{4,9}$ cranberry pomace in soy proteins,${ }^{10}$ curcumin in Saccharomyces cerevisiae, $\beta$-cyclodextrin and modified starch, ${ }^{11}$ onion and apple extracts in gum acacia and pea protein isolate or modified starch, ${ }^{12}$ blueberry in whey protein isolate, ${ }^{13}$ and so on. Ezhilarasi et al. ${ }^{14}$ reported that whey protein possesses unsurpassed nutritional quality and inherent functional properties that meet the demands of encapsulation, while Ribnicky et al. ${ }^{15}$ showed that polyphenols sorbed to soy protein isolate express higher bioavailability and bioaccessibility. In another study, ethanol extracts of ginkgo leaf were microencapsulated with maltodextrin, gum Arabic, or a soluble soybean protein by spray drying. The volume of core and wall materials had a significant influence on the encapsulation efficiency. This value was equal to $82.4 \%$ when the ratio for core material ingredients gum Arabic:maltodextrin:soybean protein was 6.1:2.87:11.75:4.28. ${ }^{16}$ Ezhilarasi et al. ${ }^{14}$ have determined the efficiency of encapsulation of the extract of Garcinia cowa on various protein and carbohydrate matrices (soy protein isolate, maltodextrin, and combinations thereof). All three materials had high encapsulation efficiency, in the range of $90-97 \%$. Umesha et al. ${ }^{17}$ examined the effectiveness of encapsulation of Lepidium sativum oil on whey proteins. It was found that the entrapment efficiency was significantly lower $(64.8 \%)$.

There are very few studies on microencapsulation of polyphenols extracted from sour cherry pomace using freeze-drying. ${ }^{18,19}$ The Republic of Serbia has very favorable natural and climatic conditions for sweet and sour cherries growing, and is a significant and promising fruit product in Serbia, primarily from the standpoint of exports to the international market. It has considerable nutritional, medicinal, dietetic and technological value. It is used in the fresh state or as a raw material, mainly in soft drinks, less in jams, yoghurt, liqueurs, brandy, compotes, and also serves as a raw material in the confectionery industry. According to the production volume of cherries, Serbia ranks seventh in the world, with a share of $7 \%$ of the total production. ${ }^{20}$ Processing of sour cherries leaves bulky by-products, such as pomace, behind every year. Sour cheery pomace is still a good source of polyphenols, particularly anthocyanins. ${ }^{21}$ According to the literature, sour cherry polyphenols have not been investigated much. Polyphenols identified in sour cherry juices, besides anthocyanins, include (-)-epicatechin (flavanol), neochlorogenic, chlorogenic and 3-coumaroylquinic acids (hydroxicinnamic acids), as well as quercetin and kaempferol glycosides (flavonols)..$^{22}$ In this study, sour cherry cv. 'Feketićka' was chosen for its more intensive taste and deeper red colour, indicating high anthocyanin content. Although grown exclusively in northern Serbian province Vojvodina, in Feketić, this variety is officially recognized, even at the international level, as a separate high-quality variety.

The present study was aimed at stabilization and concentration of polyphenols extracted from sour cherry pomace by encapsulation using freeze-drying method. Whey and soy protein were used as carriers for sour cherry pomace polyphenols. Further, the effects of storage on microencapsulated phenolics, antioxidant activity and colour parameters of powders were evaluated during 6 weeks.

\section{Experimental}

\section{1. Chemicals and Instruments}

Chemicals used in the study were of analytical grade purchased from Sigma Chemicals Co. (St. Louis, MO, USA), J.T. Baker (Deventer, Holland) and Lachner (Brno, Czech Republic). Distilled water was produced using water purification system DESA 0081 Water Still destilator (POBEL, Madrid, Spain). Soy protein isolate was purchased from "Macrobiotic prom" (Belgrade, Serbia) while whey protein was from "Lučar" (Novi Sad, Serbia).

Spectrophotometric assays were carried out using UV-1800 spectrophotometer (Shimadzu, Kyoto, Japan). Freeze drier, model Christ Alpha 2-4 LSC, was from Martin Christ, Osterode am Harz, Germany. High performance homogenizer (model Silent Crusher M) and shaker (model Unimax 1010) were from Heidolph Instruments $\mathrm{GmbH}$, Kelheim, Germany. Centrifuge, model EBA 21, was from Hettich Zentrifugen, Tuttlingen, Germany.

\section{2. Plant Material}

Ripe sour cherries, variety 'Feketićka', were purchased from local producer "Horkai", Feketić, Serbia. Fresh undamaged sour cherries were washed, all of the stones were removed by hand, and stoneless fruits were packed immediately, frozen and stored in a freezer at -20 ${ }^{\circ} \mathrm{C}$ pending further use.

\section{3. Preparation and Extraction of Sour Cherry Pomace}

Sour cherry pomace was obtained by pressing the unfrozen stoneless sour cherries through cheesecloth. The yield of pomace compared to the unfrozen fruits was $22.40 \%$. The obtained pomace was dried in a freeze drier at $-40{ }^{\circ} \mathrm{C}$ for $120 \mathrm{~h}$. The extraction of phenolic substances from dry pomace was performed using 50\% ethanol aqueous solution, according to Roopchand et al. ${ }^{10}$ Sample of pomace $(100 \mathrm{~g})$ was extracted in three steps. The first step 
includes homogenization with $500 \mathrm{ml}$ of $50 \%$ ethanol for 3 min on a high performance homogenizer followed by extraction for $60 \mathrm{~min}$ on a laboratory shaker $(200 \mathrm{rpm})$. The second and third steps were performed with the same parameters, extraction with $250 \mathrm{ml}$ of $50 \%$ ethanol for $30 \mathrm{~min}$ on a laboratory shaker ( $200 \mathrm{rpm}$ ). After each step liquid extract was collected after separating the pomace solids by vacuum filtration using Whatman filter paper $\varnothing 47 \mathrm{~mm}$. Obtained three extracts were combined and organic solvent in the collected hydro-alcohol extract was evaporated by rotary evaporation set at $40{ }^{\circ} \mathrm{C}$.

\section{4. Encapsulation of Sour Cherry Pomace Extract}

Concentrated water pomace extract $(100 \mathrm{ml})$ was mixed with wall material $(50 \mathrm{~g}$ of soy protein isolate or whey, core:coating ratio 2:1) with additional $200 \mathrm{ml}$ of water for $30 \mathrm{~min}$ on laboratory shaker $(200 \mathrm{rpm})$. The homogenized mixtures were iced and then freeze dried at $-40{ }^{\circ} \mathrm{C}$ for $24 \mathrm{~h}$, yielding red and purple-blue free-flowing powders - whey (WP) and soy protein (SP) encapsulates, respectively.

\section{5. Encapsulate Powder Storage Stability Studies}

Encapsulate samples (WP and SP) were stored at room temperature $\left(25^{\circ} \mathrm{C}\right)$ in high-density polyethylene bags for 6 weeks to determine the effect of time on the stability of total polyphenols, anthoyanins, antioxidant activity and colour parameters. For determination of the content of polyphenols and anthocyanins, as well as antioxidant activity of WP and SP, three portions of 100 $\mathrm{mg}$ of each encapsulate were removed every second week, in triplicate.

\section{5. 1. Polyphenol Content}

For determination of encapsulation efficiency phenolic content in the core (CPC) and surface (SPC) of encapsulate were determined, according to Saikia et al. ${ }^{23}$ For the core phenolic content, as well as for the storage studies, encapsulates were extracted using the following protocol: $100 \mathrm{mg}$ of powders were mixed with $1 \mathrm{ml}$ ethanol, acetic acid and water (50:8:42) on vortex for $1 \mathrm{~min}$, then centrifuged at $6000 \mathrm{rpm}$ for $3 \mathrm{~min}$. Liquid part was collected and filtered through $0.45 \mu \mathrm{m}$ filter. Similarly, for surface polyphenols, $100 \mathrm{mg}$ of sample was dispersed in $1 \mathrm{ml}$ of ethanol and methanol (1:1) mixture. The mixture was vortexed for $1 \mathrm{~min}$, centrifuged for $2 \mathrm{~min}$, and the supernatant was separated. Total polyphenol contents in encapsulate extracts were determined by Folin-Ciocalteu method given by Singelton et al. ${ }^{24}$ Results were expressed as $\mathrm{mg}$ gallic acid equivalents per $100 \mathrm{~g}$ encapsulate (mg $\mathrm{GAE} / 100 \mathrm{~g})$.
The encapsulating efficiency was determined by using the given equation:

$$
\mathrm{EE}(\%)=((\mathrm{CPC}-\mathrm{SPC}) / \mathrm{CPC}) \times 100
$$

where CPC is the phenolic content inside the core of the encapsulate; SPC is the surface phenolic content.

\section{5. 2. Anthocyanin Content}

For determination of total anthocyanins in encapsulates, the same extraction procedure as for core polyphenols was used. Total anthocyanins were determined according to the $\mathrm{pH}$ differential method by Lee et al. ${ }^{25}$ Results were expressed as $\mathrm{mg}$ cyaniding-3-glycoside per $100 \mathrm{~g}$ encapsulate (mg CyGE/100 g).

\section{5. 3. Antioxidant Activity}

The antioxidant activity of encapsulates, extracted by the aforementioned protocol for core polyphenols, was evaluated using the DPPH assay. ${ }^{26}$ Trolox was used as a positive control for callibration. Results were expressed as $\mu \mathrm{mol}$ Trolox equivalents per $100 \mathrm{~g}$ encapsulate ( $\mu \mathrm{mol} \mathrm{TE}$ per $100 \mathrm{~g})$.

\section{5. 4. Colour Parameters of Powder Encapsulates}

Encapsulate colour was measured in triplicate every second week in the period of six weeks. The CIELab colour coordinates $\left(\mathrm{L}^{*}\right.$ - lightness, $\mathrm{a}^{*}$ - redness to greenness and $b^{*}$ - yellowness to blueness $)^{27}$ were determined using MINOLTA Chroma Meter CR-400 (Minolta Co., Ltd., Osaka, Japan) using D-65 lighting, a $2^{\circ}$ standard observer angle and an 8-mm aperture in the measuring head. The Chroma Meter was calibrated using a Minolta calibration plate (No. 11333090; $\mathrm{Y}=92.9, \mathrm{x}=0.3159 ; \mathrm{y}=0.3322$ ).

\section{6. Statistical Analysis}

All data are presented as mean values of triplicate analysis along with their standard deviations. Variance analysis (ANOVA) was performed, with a confidence interval of $95 \%(\mathrm{p}<0.05)$. Statistical analyses were carried out using STATISTICA 12.0 (StatSoft, Inc., Tulsa, OK, USA).

\section{Results and Discussion}

\section{1. Sour Cherry Pomace Encapsulation}

A characteristic of bioactive food components is that they are subject to rapid inactivation or degradation. Many bioactive food components would therefore benefit from an encapsulation procedure that slows down the degradation processes and/or prevents degradation until the pro- 
duct is delivered at the sites where absorption is desired. ${ }^{28}$ Selecting the appropriate carrier for the given bioactives is a critical step. The type of coating affects the encapsulation efficiency as well as its final morphology. It has to be biodegradable, stable, avoid reaction with the bioactive, maintain the bioactive structure and improve functionality during processing and storage at different conditions. ${ }^{29}$ For our study we have chosen whey and soy proteins for coating polyphenols extracted from sour cherry pomace. The encapsulation efficiency did not differ significantly ( $\mathrm{p}$ $<0.05$ ) among the two wall materials, being higher in soy proteins $(94.90 \%)$ than in whey $(90.10 \%)$. These results show that the procedure of encapsulation of sour cherry pomace polyphenols was very successful.

\section{2. Encapsulate Powders Storage Stability Studies}

\section{2. 1. Bioactive Compounds in Powders}

The results of testing the powders' polyphenol and anthocyanin shelf life are presented in Figure 1. During the first 4 weeks the content of total polyphenols has decreased considerably in SP (70\%) and WP (80\%). However, during the last two weeks of storage, there was a significant $(\mathrm{p}<0.05)$ increase in polyphenol contents in both encapsulates, resulting in final retention $67.33 \%$ in SP and $69.30 \%$ in WP, compared to the initial polyphenol contents.

These results are in accordance with the findings of other authors. An increase in total phenolics from 2 to 2.5 fold was found after 30 days of storage at 22,37 and $45^{\circ} \mathrm{C}$ in spray-dried blueberry pomace extract encapsulated with whey protein isolate as wall material. ${ }^{30}$ The total polyphenol contents of black currant encapsulated in maltodextrin increase in the first 6 months at $8{ }^{\circ} \mathrm{C}$, while in inulin-based encapsulates they increase even after 12 months. ${ }^{31}$ Saénz et al. ${ }^{32}$ reported that cactus pear polyphenols in powders dried with inulin increase after 44 days storage at $60{ }^{\circ} \mathrm{C}$. During degradation of conjugated polyphenols free hydroxyl groups are released, causing an overestimation of the total polyphenol content determined by Folin-Ciocalteu assay. The decreases in anthocyanin levels in SP happened in the first two weeks of storage, while in WP during four weeks, and after that the content of anthocyanin levels increased, in both encapsulates. Compared to the initial concentrations of anthocyanins in encapsulates, the final concentration after 6 weeks of storage in SP has increased (for 47.97\%) and in WP it has decreased very slightly (for $1.45 \%$ ). This difference in anthocyanin retention in SP and WP encapsulates can be explained by different encapsulation efficiency in these two wall materials. Since the efficiency to encapsulate polyphenols, which includes anthocyanins, was higher in soy proteins $(94.90 \%)$ than in whey $(90.10 \%)$, more anthocyanins have remained unbound, on the surface of WP compared to SP, leading to higher degradation rate. Robert et al. ${ }^{33}$ found that anthocyanins in fresh pomegranate juice totally degraded in less than 10 days while in juice microencapsulated in SPI and maltodextrin the retention of anthocyanins was above $70 \%$ even after 60 days of storage, showing the importance of the encapsulation in preserving the bioactive compounds. In the same study it was reported that when SPI is used as a wall material both polyphenol and anthocyanin retention increase during the first 35 days of storage, possibly due to the hydrolysis of the pomegranate conjugated polyphenols, and then decrease. They showed the first-order degradation rate constant for polyphenols and anthocyanin encapsulated, calculated between 35 and 56 days. Similar behaviour was also reported by other authors. ${ }^{34,35}$

\section{2. 2. Antioxidant Activity of Powders}

Based on the retention of antioxidant activity presented in Figure 2, tested by DPPH assay, the storage affected this feature of encapsulates as well. The preservation of antioxidant activity was dependent on the material
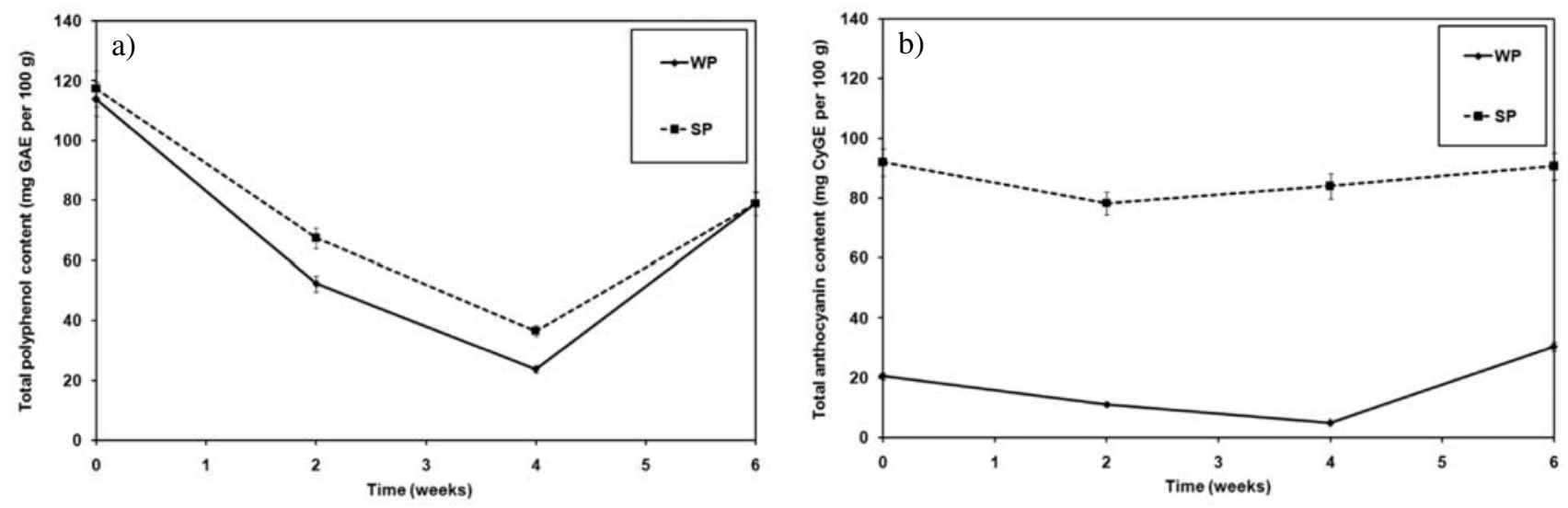

Figure 1. Polyphenol (a) and anthocyanin (b) stability of sour cherry pomace encapsulates during storage 


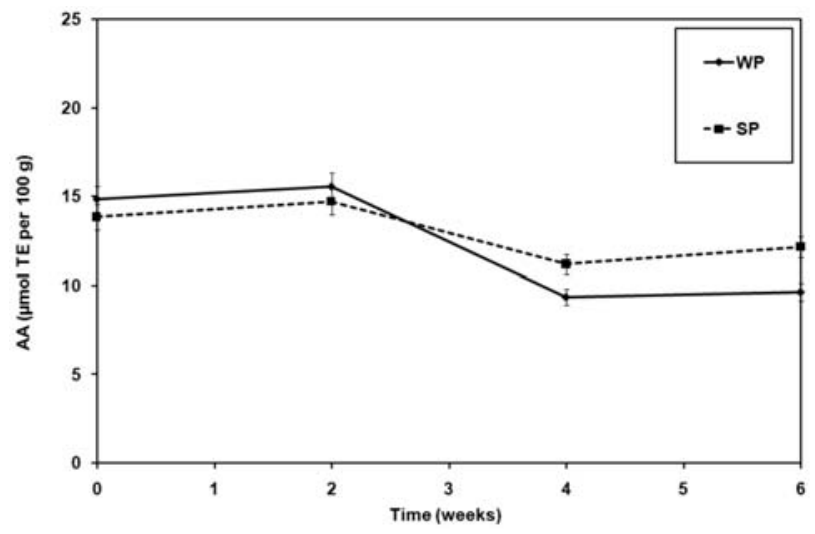

Figure 2. Antioxidant activity of sour cherry pomace encapsulates during storage

used for encapsulation, but only after the second week of storage. There was no significant diference $(\mathrm{p}<0.05)$ in antioxidant activity of powders during the first two weeks. After 6 weeks the antioxidant activity of SP $(12.13 \mu \mathrm{mol}$ TE per $100 \mathrm{~g}$ ) was almost 4-fold higher than WP (3.24 $\mu \mathrm{mol}$ TE per $100 \mathrm{~g}$ ). Final decrese in antioxidant activity after 6 weeks of storage compared to the fresh powdres in SP (12.22\%) was lower than in WP (35.04\%). This is in agreemant with the results of polyphenol and especially anthocyanin retention in powders showing the superior ability of soy proteins to bind polyphenols and anthocyanins, due to higher content of proteins.

Nori et al. ${ }^{36}$ encapsulated propolis extract employing isolated soy protein and pectin as wall materials, with relatively high encapsulation efficiency. They confirmed that encapsulation provided not only protection against degradation of phenolic and flavonoids compounds present in free propolis, but also preservation of their antioxidant properties.

\section{2. 3. Colour Parameters of Powders}

Encapsulation of natural colours can be an interesting alternative for the replacement of artificial colourants for natural colourants in the food and pharmaceutical industry. ${ }^{6}$ Change in colour parameters of sour cherry encapsu- late powders, measured by CIE L*a*b* method, during 6 weeks of storage is presented in Table 1.

According to the instrumental measurements of colour parameters it can be observed that the initial colour of WP and SP encapsulates was different (Table 1). SP encapsulate had lover $\mathrm{L}^{*}$ values (i.e. it was darker) than WP encapsulate, due to the fact that SP encapsulate showed higher initial anthocyanin content (Figure 1). Also, there was a significant difference $(\mathrm{p}<0.05)$ in redness (positive $\mathrm{a}^{*}$ values) and in yellowness/blueness ( $b^{*}$ values) between SP and WP encapsulates. WP encapsulate had higher $\mathrm{a}^{*}$ and $\mathrm{b}^{*}$ values and was coloured red, while SP encapsulate was purple-blue as evidenced by negative $b^{*}$ value $(-1.37)$. The reason for this is that the colour of anthocyanins depends on $\mathrm{pH}$. Weakly acidic medium, as whey, causes red tone coloration of anthocyanins, while in slightly alkaline conditions in soy protein isolate they change their colour to blue. Storage period and type of encapsulation agent significantly affected the colour change of encapsulates. During the storage, samples changed their colour to less intense $\mathrm{red} /$ purple-blue. In both samples, lightness ( $\mathrm{L}^{*}$ values) and redness ( $a^{*}$ values) decreased significantly $(\mathrm{p}<0.05)$, while $b^{*}$ values increased. The loss of red colour (decrease in $a^{*}$ values) was higher in WP then in SP encapsulate due to higher encapsulation efficiency of soy protein which had superior ability to bind anthocyanins, as mentioned above.

Idham et al. ${ }^{37}$ noticed the same trend (decrease in L* and $\mathrm{a}^{*}$ values, and increase in $\mathrm{b}^{*}$ values during storage) in spray dried encapsulated anhocyanins from Hibiscus sabdariffa. They also concluded that colour changes depend on the type of carriers. In SP encapsulate $a^{*}$ values decreased in the first two weeks from 16.52 to 15.09 , and then increased to 16.25 . In WP these values decreased from 25.17 to 19.23 during the first four weeks and then increased slightly to 21.88 . The increase in redness after some time could be explained by the increase in anthocyanin levels in encapsulates during storage (Figure 1).

\section{Conclusions}

Sour cherry pomace polyphenols were encapsulated in whey and soy proteins as a protecting core material.

Table 1. Colour change of sour cherry pomace encapsulates during storage

\begin{tabular}{|c|c|c|c|c|c|c|}
\hline \multirow{2}{*}{ Week } & \multicolumn{2}{|c|}{$\mathbf{L}^{*}$} & \multicolumn{2}{|c|}{$\mathbf{a}^{*}$} & \multicolumn{2}{|c|}{$\mathbf{b}^{*}$} \\
\hline & WP & SP & WP & SP & WP & SP \\
\hline 0 & $53.25 \pm 0.01^{d}$ & $47.55 \pm 0.23^{\mathrm{d}}$ & $25.17 \pm 0.4^{\mathrm{a}}$ & $16.52 \pm 0.01^{\mathrm{d}}$ & $1.47 \pm 0.75^{\mathrm{a}}$ & $-1.37 \pm 0.03^{\mathrm{a}}$ \\
\hline 2 & $51.22 \pm 0.58^{\mathrm{c}}$ & $46.21 \pm 0.14^{\mathrm{c}}$ & $22.34 \pm 0.52^{\mathrm{b}}$ & $15.09 \pm 0.23^{\mathrm{a}}$ & $4.16 \pm 0.45^{b}$ & $2.54 \pm 0.38^{\mathrm{b}}$ \\
\hline 4 & $49,41 \pm 1.02^{\mathrm{b}}$ & $45.88 \pm 0.13^{b}$ & $19.23 \pm 0.74^{\mathrm{d}}$ & $15.95 \pm 0.54^{\mathrm{b}}$ & $7.05 \pm 0.33^{\mathrm{c}}$ & $4.73 \pm 0.42^{\mathrm{c}}$ \\
\hline 6 & $48.35 \pm 0.14^{\mathrm{a}}$ & $43.75 \pm 0.26^{\mathrm{a}}$ & $21.88 \pm 0.85^{\mathrm{c}}$ & $16.25 \pm 0.55^{\mathrm{c}}$ & $10.35 \pm 1.25^{\mathrm{d}}$ & $8.29 \pm 0.35^{\mathrm{d}}$ \\
\hline
\end{tabular}

Values represent average of triplicates \pm standard deviation. Means with different letters in superscript (a-d) in columns are significantly different $(\mathrm{p}<0.05)$. 
Free-flowing powders obtained by freeze drying with high encapsulation efficiency had favourable antioxidant features (polyphenol and anthocyanin contents as well as antioxidant activity on DPPH radicals) and colour parameters, even after six weeks of storage. From the results presented herewith it can be concluded that the sour cherry pomace encapsulates represent a promising food ingredient for functional food development, due to both antioxidant content and potential as a colourant. The results of this study also suggest that encapsulation can be regarded as a final stage of high added-value compounds processing from food wastes. Future studies will involve incorporation of encapsulates in a food model system to test the influence of other components as well as food processing parameters on stability of encapsulated bioactive compounds.

\section{Acknowledgements}

This research was supported by the grant from the Ministry of Education, Science and Technological Development of Serbia (project No. TR 31044).

\section{References}

1. O. I. Parisi, F. Puoci, D. Restuccia, G. Farina, F. Iemma, N. Picci, in: R. R. Watson, V. R. Preedy, S. Zibadi (Eds.): Polyphenols in Human Health and Disease, Elsevier, Academic Press, London, 2014, pp. 29-45.

https://doi.org/10.1016/B978-0-12-398456-2.00004-9

2. X. Zhang, F. Chen, M. Wang, J. Agric. Food Chem. 2014, 62, 1643-1648. https://doi.org/10.1021/jf4045827

3. A. Scalbert, C. Morand, C. Manach, C. Rémésy, Biomed. Pharmacother. 2002, 56(6), 276-282. https://doi.org/10.1016/S0753-3322(02)00205-6

4. M. Paini, B. Aliakbarian, A. A. Casazza, A. Lagazzo, R. Botter, P. Perego, LWT - Food Sci. Technol. 2015, 62, 177-186.

5. M. Çam, N. C. İçyer, F. Erdoğan, LWT - Food Sci. Technol. 2014, 55, 117-123.

6. K. Ravichandran, R. Palaniraj, N. M. M. T. Saw, A. M. M. Gabr, A. R. Ahmed, D. Knorr, I. Smetanska, J. Food Sci. Tech. 2014, 51(9), 2216-2221.

https://doi.org/10.1007/s13197-012-0728-6

7. E. Janiszewska, Powder Tech. 2014, 264, 190-196. https://doi.org/10.1016/j.powtec.2014.05.032

8. C. Chranioti, A. Nikoloudaki, C. Tzia, Carbohydr. Polymer 2015, 127, 252-263. https://doi.org/10.1016/j.carbpol.2015.03.049

9. D. Pasrija, P. N. Ezhilarasi, D. Indrani, C. Anandharamakrishnan, LWT - Food Sci. Technol. 2015, 64, 289-296.

10. D. E. Roopchand, C. G. Krueger, K. Moskal, B. Fridlender, M. A. Lila, I. Raskin, Food Chem. 2013, 141, 3664-3669. https://doi.org/10.1016/j.foodchem.2013.06.050

11. E. I. Paramera, S. J. Konteles, V. T. Karathanos, Food Chem.
2011, 125, 913-922.

https://doi.org/10.1016/j.foodchem.2010.09.071

12. N. Işık, B. Alteheld, S. Kühn, N. Schulze-Kaysers, B. Kunz, H. R. Wollseifen, P. Stehle, S. Lesser, Food Res. Int. 2014, 65, 109-114. https://doi.org/10.1016/j.foodres.2014.02.012

13. F. P. Flores, R. K. Singh, W. L. Kerr, D. R. Phillips, F. Kong, Food Chem. 2015, 168, 225-232. https://doi.org/10.1016/j.foodchem.2014.07.059

14. P. N. Ezhilarasi, D. Indrani, B. S. Jena, C. Anandharamakrishnan, J. Food Eng. 2013, 117, 513-520. https://doi.org/10.1016/j.jfoodeng.2013.01.009

15. D. M. Ribnicky, D. E. Roopchand, A. Poulev, P. Kuhn, A. Oren, W. T. Cefalu, I. Raskin, Nutrition 2014, 30, S4-S10. https://doi.org/10.1016/j.nut.2014.03.009

16. L. Haidong, Y. Fang, T. Zhihong, S. Huanwei, Z. Tiehui, Carbohydr. Polymer. 2012, 88(2), 435-440. https://doi.org/10.1016/j.carbpol.2011.12.025

17. S. S. Umesha, R. S. Manohar, A. R. Indiramma, S. Akshitha, K. A. Naidu, LWT - Food Sci. Technol. 2015, 62, 654-661.

18. B. Cilek, A. Luca, V. Hasirici, S. Sahin, G. Sumnu, Eur. Food Res. Technol. 2012, 235, 587-596. https://doi.org/10.1007/s00217-012-1786-8

19. V. Tumbas Šaponjac, G. Ćetković, J. Čanadanović-Brunet, B. Pajin, S. Djilas, J. Petrović, I. Lončarević, S. Stajčić, J. Vulić, Food Chem. 2016, 207, 27-33. https://doi.org/10.1016/j.foodchem.2016.03.082

20. Z. Sredojević, D. Milić, M. Jeločnik, The Petroleum-Gas University of Ploiestie Bulletin 2011, 63(3), 37-49.

21. C. Yılmaz, V. Gökmen, Ind. Crop. Prod. 2013, 49, 130-135. https://doi.org/10.1016/j.indcrop.2013.04.048

22. D. Bonerz, K. Würth, H. Dietrich, F. Will, Eur. Food Res. Tech. 2007, 224, 355-364. https://doi.org/10.1007/s00217-006-0328-7

23. S. Saikia, N. K. Mahnot, C. L. Mahanta, Food Chem. 2015, $171,144-152$. https://doi.org/10.1016/j.foodchem.2014.08.064

24. V. L. Singleton, R. Orthofer, R. M. Lamuela-Raventos, in: L. Packer (Ed.): Methods in Enzymology, Oxidant and Antioxidant (Part A), vol. 299. Academic Press, San Diego, 1999, pp. 152-178. https://doi.org/10.1016/S0076-6879(99)99017-1

25. J. Lee, R. W. Durst, R. E. Wrolstad, Journal of AOAC (Association of Official Analytical Chemists) International 2005, 88(5), 1269-1278.

26. V. Tumbas Šaponjac, A. Gironés-Vilaplana, S. Djilas, P. Mena, G. Ćetković, D. A. Moreno, J. Čanadanović-Brunet, J. Vulić, S. Stajčić, M. Vinčić, RSC Adv. 2015, 5, 5397-5405.

27. CIE International Commission on Illumination, Colorimetry: Official Recommendation of the International Commission on Illumination, Publication CIE No. (E-1.31), 1976, Paris, France: Bureau Central de la CIE.

28. P. de Vos, M. M. Faas, M. Spasojevic, J. Sikkema, Int. Dairy J. 2010, 20, 292-302. https://doi.org/10.1016/j.idairyj.2009.11.008

29. M. D. A. Saldana, J. S. dos R. Coimbra, L. Cardozo-Filho, 
Current Opinion in Food Science 2015, 5, 76-85.

30. F. P. Flores, R. K. Singh, F. Kong, J. Food Eng. 2014, 137, 1-6. https://doi.org/10.1016/j.jfoodeng.2014.03.034

31. A. M. Bakowska-Barczak, P. P. Kolodziejczyk, Ind. Crop. Prod. 2011, 34, 1301-1309.

https://doi.org/10.1016/j.indcrop.2010.10.002

32. C. Saénz, S. Tapia, J. Chávez, P. Robert, Food Chem. 2009, 114, 616-622. https://doi.org/10.1016/j.foodchem.2008.09.095

33. P. Robert, T. Gorena, N. Romero, E. Sepulveda, J. Chavez, C. Saenz, Int. J. Food Sci. Tech. 2010, 45, 1386-1394. https://doi.org/10.1111/j.1365-2621.2010.02270.x
34. A. Stewart, S. Bozonnet, W. Mullen, G. Jenkins, E. Michael, A. Crozier, J. Agric. Food Chem. 2000, 48, 2663-2669. https://doi.org/10.1021/jf000070p

35. N. Turkmen, F. Sari, Y. Velioglu, Food Chem. 2005, 93, 713-718. https://doi.org/10.1016/j.foodchem.2004.12.038

36. M. P. Nori, C. S. Favaro-Trindade, S. Matias de Alencar, M. Thomazini, J. de Camargo Balieiro, C. J. Contreras Castillo, LWT - Food Sci. Technol. 2011, 44(2), 429-435.

37. Z. Idham, I. I. Muhamad, M. R. Sarmidi, J. Food Process. Eng. 2012, 3, 522-542.

https://doi.org/10.1111/j.1745-4530.2010.00605.x

\section{Povzetek}

V tej študiji smo tropine višenj ekstrahirali s $50 \%$ etanolom, ji koncentrirali in stabilizirali z enkapsulacijo z uporabo sirotkinih in sojinih proteinov. Učinkovitost enkapsulacije je bila večja pri uporabi sojinih proteinov (94,90 \%), a ne statistično značilna ( $\mathrm{p}<0,05)$, kot pri uporabi sirotkinih proteinov $(90,10 \%)$. Preverili smo tudi stabilnost enkapsulatov s proteini sirotke (WP) in soje (SP) med skladiščenjem v obdobju šestih tednov, kjer smo se osredotočili na vsebnost celokupnih polifenolov in antocianinov ter antioksidativno aktivnost. Po končanem obdobju skladiščenja je bila vsebnost polifenolov v enkapsulatih SP in WP podobna $(67,33 \%$ in 69,30 \%), vsebnost antocianinov v SP se je povišala (za 47,97 \%), v WP pa zmanjšala (za 1,45 \%). Antioksidantivna aktivnost enkapsulatov z SP se je znižala (12,22 \%), a manj kot v primeru enkapsulatov z WP $(35,04 \%)$. Skladno s spremembami, ki smo jih med skladiščenjem zaznali pri antocianinih, se je spreminjala tudi barva enkapsulatov. Opisana tehnika omogoča pripravo kakovostnih enkapsulatov, ki se jih lahko uporabi kot funkcionalne aditive v živilih in se s tem izkoristi vrednost sadnih odpadkov. 